\title{
Loss of Chromosome 8
}

National Cancer Institute

\section{Source}

National Cancer Institute. Loss of Chromosome 8. NCI Thesaurus. Code C36535.

A cytogenic abnormality that refers to loss of all or part of chromosome 8. 